\title{
堀 晄氏の書評論文（オリエント35-2）に応える Reply to Mr. Hori's Comment on Tell Kashkashok, The Excavations at Tell No. II
}

カシュカショク II 号丘のP 9 は豎穴住居であっただろらか

——書評論文」に応える——

Reconsidering the Function of P9 found at

Tell Kashkashok II, Syria

\author{
松谷 敏 雄 \\ Matsutani Toshio
}

はじめに

1987年と88年の 2 年間, それぞれ 3 ケ月ていどの期間, シリア東北部ハブール平原に あるカシュカショクII 号丘の発掘調查を筆者らは実施した。その報告書は1991年の春に 出版された。この発掘報告書に関して, 堀 (1992) が本誌においては新しいカテゴリー である「書評論文」といら形式のもとにとりあげ，「内容に関して批判，疑問点を提出 し，報告者からの反論を受けたい」(堀1992：143）と述べた。本稿はそ机に応えるすの の一部である。

\section{P9について}

報告書を編集しているとき，メンバーのひとりである西秋から，P 9 は住居址ではな いのではないかと強い異論が出されていた。筆者が堅穴住居だと思いこんでいたことと 西秋がロンドンへ留学中といらことも手伝って, 手紙でのやりとりでは十分な議論をつ くせないまま，今回は筆者の意見を通させてほしいと，かれを十分納得させる努力をし ないで，編集作業を進めたといらいきさつがある。このたび，堀（1992）の「書評論 文」にいかように対応するかを相談し，分担を決める際に，西秋には異論をぜひ展開し てほしいと希望し，まとめられたのが本号の論文（西秋1993：100）である。

西秋は，P9のようなピットが住居であったか否かについて，4つの側面から論じて

* 東京大学東洋文化研究所教授

Professor, The Institute of Oriental Culture, The University of Tokyo 
いる。このうち, 最後の生態学的検討を除く 3 点, つまり (1) 考古学的分析, (2) 歷史的脈絡，（3）民族誌的類推に関してはとの主旨が主張されていた。もちろん今回 まとめられた論文のよらに詳細にはわたっていなかったが，当時の手紙（1989年12月 4 日付）を読みかえしてみると，すでに根拠として主張されていた重要な点（たと党ば西 秋1993：表 1，2）の意味を筆者が理解できていなかったことに気付いた。これは筆者 炕は，P 9 が堅穴住居であったという思いこみがあり，西秋の主張する根拠を偏光フィ ルターによって遮断してしまったために生じたものと思われる。

今，振りか党ってみれば，思いこみは随所にみられる。1 例だけ1987年の調査の予報 の中から出しておく（松谷1989：8）。

「この層の名称は意図的に「第 3 層」とかつこをつけて呼ぶことにした。その理由を

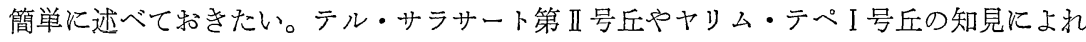
ば，ハッスーナ I a 期の最初の居住は堅穴住居であった。のちになって，土器やその他 の文化遺物にはほとえぞ違いは認められないのに，住居だけが変り，地上にタウフで建

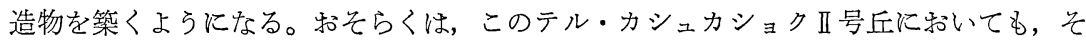
らした変化があったにらがいない。もしとらだとすれば，いいかえれば，第 2 次調査で 地上で築かれた建造物の層位の存在が確認できれば，この層こそ第 3 層と呼ばれるにる さわしい。として，竪穴住居は，第 4 層と呼ばれなければならない。堅穴住居の層を第 1 次調査に持いて第 3 層としてしまえば，もし第 2 次調査で本来の第 3 層の遺構を確認 したとき，変更を余儀なくされる。層位の名称の変更は，発表してしまった後では大層 混乱のもとになるし，徹底させることは意外にむづかしい。こうした配慮のもとに，第 1次調査に拈いては，堅穴住居の層位を意識的にかっこをつけて「第 3 層」として発表 するわけである。そして，第 2 次調査で本来の第 3 層ががみつかったとき，第 1 次調査 に括ける「第 3 層」を第 4 層に変える方針である。

この時期の文化に初めて遭遇した場合ならばともかく，他の遺跡での知識もあるとき にはこうした配慮も理解されるものと考える。」

こうした思いこみによって，P 9 を住居とみなしてしまったのである。西秋によって P 9 の正しい位置づけがなされた以上，P 9 を住居址とみることはできなくなった，と いわざるをえない。堀の次の指摘はまことは正しいと思う。

「「サラサートXII層＝半地下式住居」といら仮説は，もはや捨て去るべきで，過去の 経験にこだわりすぎると，実際の姿を見誤ってしまらことになるのではないだろらか」 （堀1992: 147)。西秋（1993：111）は，「調査団の公式見解に反する意見を述べるこ とは心苦しいかぎりだが，これもカシュカショク調査の一つの成果であると考えていた だケれば幸いである」といらが，決して，心苦しく思ら必要はない。筆者も若い頃，先 
輩に随分「くいついてきた」が，今は「くいつかれる」立場になったと思わざるを党な い。これは研究全体としては進歩している証拠であるら。いずれにせよ，サラサートに 参加した堀とカシュカショクに参加した西秋の 2 人によって, 正しい見通しが兄られた ことはまことによろこばしいといらべきであろう。これからもどしどしやってもらいた い。

次に，時期名称については簡単に述べる。筆者自身も，この時期に「適切な」名称が 与えられることを望んでいる (Fukai and Matsutani 1981：65)。しかしまだ定着し ているとはいいがたい。そこで筆者は意戝的に「ハッスーナI a」を用いているにすぎ ない。この問題は，いずれ時間が解決してくれるものと期待している。

\section{2. 編集者の責任について}

堀（1992：153-154）は第 1 層出土の Seal の比定に触れて, 報告書全体の信用が問わ れると強く指摘している。この件に関しては, 千代延が別稿をもって反論する予定であ り，その論争の結着をまって，「信用」なり「責任」の所在を明らかにしたいと考光る。 評者の一方的な見解に立脚しての論法には従光ないからである。また評者の比定が誤っ ているとされた場合には，それなりの弁明をしていただきたいとも思っている。

\section{おわりに}

筆者は，発掘とは報告書の刊行をもって終るものと考えてきた。本報告が出ないまま， 概報による発掘者の見解を強制されることがいかに多いことか。発掘は破壊である。遺 跡の破壊が考古学者に許されるのは, 報告書といら形で, いかに遺跡を破壊したかを世 に公刊する義務を負っているからであるう。報告書を刊行しない発掘は，盗掘者による 遺跡の破壞と何ら変る所がない。

堀による「書評論文」が執筆されたのる, 報告書の出版が前提となっていることは否 定し亲ないであろら。発掘者は, 何らかの仮説をるって遺跡を発掘調査する。その仮説 の中には，改めなけ就ばならないものもあろら。その上でまた新たな仮説も生じてくる。

こうした考方方をする筆者は，堀の「書評論文」や西秋の本号の論文を大いに歓迎す るものである。

\section{注}

（1）シリアのハブール平原の遺跡は，シリアの古物当局がたと党ひとつの名を与えて いても，それらのほとんどはテル群である。カシュカショクの場合も例外ではない。 1985年の夏休みを利用して，発掘するに適した遺跡の選定にでかけた。当時古物当 局は，ハブール川の建設されるダムによって水没する遺跡の発掘に全力を注いでい 
た。紹介されたのは, ハッサケ市の南に33，北に 6 の登録された遺跡であった。筆者 ら（松谷と古山）は, これらの遺跡をすべて訪れた。訪れたテルの数は39の数倍にお よぶ。選定作業の終了間近かになってみつかったのが，のちにカシュカショク II 号丘 と名付けられることになる遺跡であった。

アレッポ博物館のアントワン・スレイマン博士もカシュカショクの一番大きいテル を発掘したいと希望していた。そこで, 1987年の発掘に先立ち, アレッポで同博士と 会い,カシュカショクの遺跡にあるテルにそれぞれ番号をつけることにした。ワジの 西側に位置する低い円形のものをI 号丘 (これはのちに同博士によって試掘された),

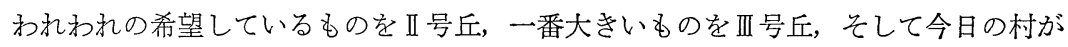
営まれているものを $\mathbb{N}$ 号丘とすることに合意した。この結果, われわれの掘るテルの 名がカシュカショク II 号丘と決まったのである。

（2）堀の指摘する批判・疑問点は多岐にわたる。ほぼ次のように分けられるとわれわ れは考えた。(1)第 4 層, 第 3 層問題。ここには層位の問題とP 9 が堅穴住居であった のかといら問題提起が含まれる。(2)第 2 層問題。ここには編年問題がある。(3)第 1 層 問題。ここでは時期決定の問題が重大である。ついで最後に(4)編集者の責任問題とな る。

本稿でとりあつからのは，主として(1)のうちのP 9 に関してと(4)についてである。 (1)のらら，層位については，古山が，(2)と(3)に関しては，それぞれ担当した小泉と千 代延が別稿を笴せる予定となっている。

\section{引用文献}

Fukai, S. and Matsutani, T.

1981 Telul eth Thalathat, vol. IV, The Institute of Oriental Culture, The University of Tokyo.

堀 晄

1992 「テル・カシュカショク発掘報告書をめぐって」『オリエント』35-2:143-155 西秋良宏

1993 「北メソポタミア土器新石器時代初頭の堅穴掘削行動』『オリエント』36-2： 100-119

松谷敏雄

1989 「カシュカショク I 号丘の発掘一1987年一」『東洋文化研究所紀要』第109冊： $1-33$ 


\title{
テル・カシュカショク第 3,4 層について \\ 一堀 晄氏の書評に応兑る—
}

The Layers 3 and 4 of Tell Kashkashok II

\author{
古山学 \\ FURUYAMA Manabu
}

\section{はじめに}

堀晓氏が本誌 35 巻 2 号に，われわれの発掘報告書に対する批判的な書評を寄稿され た。そのことは，議論を深めるといら意味で歓迎するものであり，また氏の労を多とし たい。

しかしながら，誤解にもとづいて議論が行なわれた場合には，その議諭は生産的なも のになり難いと考学る。堀氏の批判のなかにそうした誤解ではないかと思われるるのが あり，私が担当した層位の問題についても，そのことを強く感じたので，以下に正確な 理解が得られるよう述べてみたい。

\section{1. 第 $3 ， 4$ 層はどのように区分されたか}

まず，堀氏が「上述の記述からすれば，『Level 4 と Level 3 は Bedrock 上面で 一致しているが, Layer 4 と Layer 3 は実在し，そこに含まれる遺物は様式的に区別 乙得る』と主張されているのである。とカギ括孤るつけて述べている部分である(145 頁)。私はそのような主張は一言も述べていないから，これは堀氏の解釈であると判断 される。ここでの問題は, Layer 4 と Layer 3 の遺物は「様式的に区別し得る」と 堀氏が推測したことである。堀氏がとりあげた報告書の10頁と11頁では，テル・カシュ カショク II 号丘の層位を記述しているので, ここでは遺物の問題は一切触机ずに, 層位 と遺構との関係だけを述べている。したがって, tauf-walled room Layer 3, P9 を Layer 4 としたからと云って，私がそれぞれの層に含委れる遺物は様式的に区別される と考觉ているとみる根拠はないわけで，堀氏のような推測がどうして出てくるのか私に はわからない。堀氏は層を分けた以上，遺物は様式的に区別されている筈だあるいは， 遺物が様式的に区別されない限り，層を分けてはいけないと云う考方方を持っていて， それを私にあてはめて推測をしたといらことになるが，ぞらであるらか。しかしそれは

* 東京大学東洋文化研究所文部技官

Technical Official, The Institute of Oriental Culture, The University of Tokyo 
堀氏の考光方であって，私は責仕を持つわ㤝にはゆかないのである。

土層図は指摘の通り，暧眜なところがあることは否めない。しかし tauf-walled room は，その壁や床と bedrock との境が遂に把握出来なかったといらのが事実である。壁 と床に石膏が塗って㐫ったので, すぐにこれが遺構であると判断出来たのだが, 壁と床 は bedrock と同じ土で作られていたために区分出来なかった。またこの遺構のレベル と, P9 pit-house の掘り込反面との関係も，層位を明確にしなければならないと考光， かなりの時間をかけて追跡をしたのであるが，最下層の層位区分が出来なかった。した がって，その結果として tauf-walled room は bedrock の上に作られ，P9 は bedrock を掘り込んで作られているという関係だけが把握出来たのである。

そこで報告書の記述の通りこういう関係の場合，一般には同一時期の遺構と考光る 方が自然であるが，テル・サラサートII 号丘で pit house が tauf-walled construction の下層から出土していたことを踏秃てて テル・カシュカショクのP9 は Layer 4, tauf-walled room は Layer 3 であると判断を示したのである。私の判断の根拠はこ

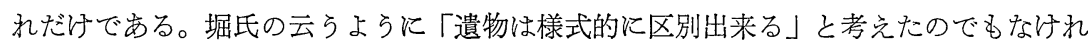
ば，また「半地下式住居説を補強するものとして第 3 の説明に飛びついた」（147頁）， つまり「層位によるインダストリーの差を示す」という打製石器の統計処理の結果を, 我田引水的に補強のために使掞らとしたわけでもない。報告書の記述を素直に読んで批 判をしていただければ良いのである。

\section{2. $\mathbf{D} / 8$ pit について}

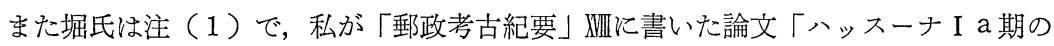
集落」を引用して,「Layer 4 と 3 の間で遺物の面では全く違いがないと論じている」 から，「D/8 pit L Layer 3 飞する根拠は消隇する」。と述べている。そもとも打製石 器の統計処理の結果を, P 9 が堅穴住居である根拠にしようとしたのではないかという のは，堀氏の推測である。堀氏は憶測にもとづいて，私がこの統計処理の結果に「飛び ついたのではないか」としたのである。したがって，私はこのような憶測に責任はない。 私ははじめから Layer 3 と 4 の間には, 遺物の差がないと考光ていたので, そのこと を私の論文書いたのである。

報告書の $\mathrm{D} / 8$ pit 蒿記述した部分（17頁と18頁）を読んでみていただきたい。 D/8 pit がタウフ壁の土を採った穴であるとしたら，これは Layer 3 に属するし，またこれ がP 9 と同時期の遺構と考えるなら Layer 4 飞属すると述へ，最終的な判断は，この 穴を完掘していないことから保留をしているのである。このように, D/8 pit を Layer 3 飞決めたわけではないので，堀氏は注（1）で「Layer 3にする根拠は消隇する」と 
述べているが，根拠にしていないものが消隇する筈もない。

\section{3. 層位区分をする際の考え方}

テル・カシュカショクII号丘の第 $3 ， 4$ 層を区分する際の私の考え方は, 以上述べて 来たことから明らかであるが，改めてまとめておく。われわれは，P 9 の遺構を発掘し た時に，その状態からこれを豎穴住居と判断し，テル・サラサートII 号丘XV，XI層の例 からこれがタウフ壁を持つ住居よりも先行する可能性が強いことから，P 9 の層位を Layer 4 としたのであった。そのことは報告書に明確に記述してある。堀晄氏は，これ が堅穴住居ではないといら立場から批判を加えたわけだが，その場合に，第 3，4層を 区別する根拠がないことを立証して，㹂穴住居説を否定する材料にしょうとしたわけで ある。しかも，私が論拠にしていないことや，考えてもいないことを掘氏の憶測を付け 加壳てとりあげ，批判をしてみせたのである。堀氏は自分で論拠を作り出してそれを批 判してみせ，私が間違っているといらのである。これは正しいやり方だろらか。あえて 一言云わせて貪うなら，P9 は堅穴住居ではないという意見を云う場合，このような無 理をして層位の問題をとり上げる必要はなく，堀氏自身の論㚭にもとずいてこの遺構の 性格を論証してみれば良かったのである。

私は遺跡に特いて層位を分ける場合，常にその理由を明確にしてあり，またとの理由 を報告書に記述している。あれこれの憶測を加兄る必要は全くなく，私が提出した理由 を理解し，それを批判していただければ幸である。

\section{おわりに}

堀氏の書評がきっかけとなり, 西秋良宏氏が大変説得的な論文「北メソポタミア土器 新石器時代初頭の㹂穴掘削行動」を本誌に発表したことは，研究の一歩前進と評価出来 るもので, やはり議論があってこそこのような成果が得られたのであると，その点を堀 氏に感謝している。この西秋論文によってP 9 の遺構をどら考光るかは, 松谷敏雄氏が 述べているが，その結果としてP 9 の層位をどのように決めるかは，自ら明らかである ら。

調査団の公式な見解は松谷氏の文に述べられている通りであるが，私自身は，テル・ サラサートII 号丘XI層で出土した穴の中に黒灰が充満し，その直上にタウフ壁の住居が 建てられている例から，タウフ壁住居の居住に先立って，それと異なる居住形態があっ たとする考方方は変っていない。この問題の解決は, 当該期の遺構の資料がもっと多く 得られることによって解決されるだろらと考光ている。 


\section{テル・カシュカショク出土の封印 \\ 一一堀氏の批判に応光て一一 \\ The Seals from Tell Kashkashok}

\section{千代延 恵 正 CHIYONOBU Yoshimasa}

堀晄氏がオリエント 35 巻 2 号に書かれた我々の報告書「カシュカショク」に関するま ことに優れた，また自信にあられた書評論文を読みとの鋭く䈗しい研究姿勢と明確な批 判に祈を正す思いをいたした次第である。堀氏の批評にはお打いに反省する部分もある がまた同時に堀氏の一方的な解釈を感ずる部分もあり，ここに改めて堀氏が私の報告部 分に対して行なった批判に拉応えをすることにしたい。

堀氏の私の報告に対する批判の第一は第 1 層の年代の記述が不明確なこと, おちよび報 告した土器を安易に Tell Leiran V 層の土器に比定していることである。

先ず第 1 層についてであるがこの層は風雨等の自然的条件，また耕作等による人為的 条件による破壞により層全体がひどく荒らされて招り，報告書にもある如く年代的考察 を行ならことは不可能であり,この層についての検討はなされていないのが実情である。 従って我々はこの層の年代については具体的な見解を有していない。第 1 層の出土資料 にはイスラム期も含めて多岐にわたり，しかも出土状況も断片的であり遺構に関しても 殆んぞ不明であった。その点では第 1 層の遺物，とりわけ土器に関して充分の整理検討 された形で報告出来なかったことは我々としても残念なことであった。Tell Leiran V 層の土器に近いとの記述については報告者 Schwarz の記述と我々の資料が医ぼ一致す ると判断したためであるが，我々が Tell Leiran V 層の土器を実見していない状態で軽 々にこのよらな判断をすることには慎重であるべきであったと堀氏の指摘を心して受け とめたいと考えている。

次に堀氏は第 1 層出土資料のなかの「封印」の報告で報告者たる私が用語として seal を用いていることに関連して，報告された資料は sealing つまり「封泥」であって seal つまり「印章」ではない。報告者は seal と sealing を取り違えている。報告者のこの

* 東京大学東洋文化研究所文部技官

Technical Official, The Institute of Oriental Culture, The University of Tokyo 
よらな䛊認は後述する年代の問題も含めてこの報告書の信頼性を欠くとしている点であ る。

この堀氏の批判は私にはいささか的外れの気がしている。なぜなら私はこれらの土製 品に「ひも」あるいは「縄」の圧痕があることを観察したらえでこれらを「封印」と判 断し，それにふさわしい英語として seal を用いたからである。 seal といら語は英語 圈の人たち，また英語を理解する人たちにはこの語で充分に「封印」として通じるから である。そこで，ここでは seal といら語について英語一般論として再考し堀氏へのお 応光としたい。

さて，英語の知識のある人であれば竞知のことであるが英語では「印章」・「封印」 ともに seal という語を用いるのであり，印章を使う習慣の少ない英米人にとっては seal といらのはむしろ「封印」といら感覚のほうが強いということを申し上げて括こ (4) 亏。

英米人にとって日本語でいうところの「印章」を表現する場合には stamp， stamp seal, flat stamp, seal cylinder 等が用いられ, seal イコール「印章」とはとらえ ていないのが一般的である。 sealing が「封印」の意で用いられる場合もあるがその場 合には impression on clay sealing の上うに熟語として用いられ sealing 単独では 堀氏の言う「封印」ましてや「封泥」の意はないのである。

また同氏は『“seal”ではなく“impression”であって封泥，つまり“sealing”之呼ぶ ベきである』と記して「impression」イコール「封泥」イコール「sealing」と考㝋て抒 られるが impression という語は「紙や布，あるいは封口ウに押された印章の印面」の ことであり, 従って impression の語は印章によってつけられた印面の「図柄」「文 栐」あるいは「文字」そのるのを指するのであって「封印」ましてや「封泥」を示する のではない。

堀氏の批判は外国語で文章を書くにあたってはとの言語の単語や文を日本語の感覚で 恣意的に判断することはかえって誤解を招く危除性があるということをはからずも示し ているといえよう。

堀氏の次の批判はこれらの「封印」の年代について報告者が何の根拠も示さずにグレ コ・ロマン期のものと報告した点についてであり，堀氏はいくつかの論拠を挙げてジュ ムデド・ナスル期のものと断定し, 我々の報告書に対する不信感を表明していることで ある。

さて，それでは堀氏が指摘したこれらの「封印」の年代について，先ずワシの「図 柄」から考えてみることにしたい。堀氏も書いているようにジュムデド・ナスル期の印 
章の印面等に表現されたワシの図は正面を向いて翼を大きくはばたいて飛翔する，そし て左右に伸ばした脚で犠牲や動植物をつかむ姿であらわされるのである (Fig. 1〜3)。 またワシが横向きに表現される場合には犠牲の肉をついばんでいる姿が多く，ワシの体 は直立せずに頭を下げて体を水平にしているのである (Fig. 4)。その他にも獲物を狙ら かのように体を低くして何かをらから゙うような姿で表現されるものもある。また，地上 に降り立ち，翼をたたんで周囲を威圧するように直立するワシの姿はジュムデド・ナス ル期には認めることができない。さらに構図上でも翼をひろげて飛翔するワシは全て画 面の中央部に置かれ（Fig. 1 3)，地上で儀牲をついばむワシは構図全体の中の点景と して描かれるのが一般的である (Fig. 4. 5)。

ところでカシュカショクの「封印」にみられるワシの図は地上に降りて翼をたたみ背 中を伸ばして遠くを見つめて直立した右横向きの姿で表現されている (Fig. 18)。この ように地上で翼をたたみ，あるいは半分ほど拡げて周团を威圧するかのように直立する ワシの姿はローマの伝統的な様式であり，その影響の及んだ西アジアの遺跡，例えばド ゥラ・ユーロポス，ハトラ，パルミラ等の浮彫りに多くの例が認められる (Fig. 9, 11 〜14)。末た，このようなワシの姿は印章，丸彫りの石像，鋳造による青銅製小像 (Fig. 10）などの例も多い。浮彫りの場合などには横向きのワシのみならず正面向きのものも あり (Fig. 12，13)，さらにハトラの例の如く神像の背側面コーナー部分に背面よりみた ワシの姿をアプリケのように表現したもの等も認められる（Fig. 15)。戝像表現上も 翼, 尾羽, 脚等ワシの各部を正確に観察して表出している。さらに構図の上からもこれ らのワシが主題のアットリビュートとして表現される場合には方形に作られたフレーム の端部にいっぱいの高さに表現されるか（Fig. 9, 11〜13）あるいはコーナー部分に配置 されることが多いのである (Fig. 14)。カシュカショク出土の封印に表現された右向き に直立するワシの図像は稚拙で多少硬化した表現であるがその姿勢, 翼, 尾羽, 脚等の 様式，さらにフレーム端部に高さいっぱいに配置する構図等グレコ・ロマン期のものと 考光て差仕光ないのである。むしろ堀氏が招介したジュムデド・ナスル期の例とカシュ カショク出土のワシを比較すること自体に無理があると言えよう。

次に人物像の図柄の封印であるが，堀氏の招介した円筒印章の図柄にもあるようにウ ルクやジェムデド・ナスル期に印面の人物は労働，儀式あるいは日常生活等何らかの動 作をしている場面が大部分であり，乙かも身体全体が横向きに表現されているものが圧 倒的に多い (Fig. 5 8)。

カシュカショクの例は堀氏の言う如く座した人物が仕事をしているという図ではなく， 明らかに大きくふくらんだ髮形をした細面の人物が長衣を着用して正面向きに直立して いる図柄と考号らる（Fig. 19）。このよらなポーズの人物像はドゥラ・ユーロポス， 
パルミラ, ハトラ等の出土品や壁画, 浮彫り等には多くの例があり, 表現様式的にもグ レコ・ロマン期のものと考党ることが出来る (Fig. 16，17)。

堀氏がへビのからまった文様と判断して扔られる資料については報告者には全くその ようには判断できなかった (Fig. 20)。ジュムデド・ナスル期のものであるといら先入 感がへビの姿を印面にみてしまったのだろうか。

以上述べたような理由でこれらの年代についてはグレコ・ロマン期に属するるのであ り，これらがジュムデド・ナスル期に属するといら堀氏の見解には大なる疑問をいだく ものである。

以上ではたして堀氏への扔応えになったか否かいささか心もとないが私の見解を申し 述べさせていただいた。またこの機会を拈借りして堀氏の深い学識と鋭い観察力, そし て学閭に対する自信あふれた姿勢には心からの敬意を表させていただくものである。

注

（1）堀氏の私の報告に対する批判は第 V章にあたる部分である。また堀氏の書評論文 第 3 項のタイトルが「 3 第 3 層に関して」となっているのは堀氏の校正ミスで「第 1 層汇関して」が正しいと思われる。

T. Matsutani, Tell Kashkashok, The Excavations at Tell No. II, 1991 (以下 Kashkashok 1991): Chap. VI Artifacts from Layer I p. 81 参昭

(2) Kashkashok 1991; Chap. I-3 The Stratigraphic Layers of Tell No. II 参 照

(3) T. Iwasaki and J. Kawamura, Kenkyusha's New English-Japanese Dictionary, 1960 (以下 Kenkyusha 1960) 飞上れば Seal 飞は「印, 印形」と「封, 封印」の両方が揭載されている。これは他の英和辞典でも全て同様である。

(4) C. T. Onions et al (ed.) The Shorter Oxford English Dictionary on Historical Principles, The Third Edition, 1968 (以下 Oxford 1968)によれば seal の項目では第 1 項目に

(A) A device impressed on a piece of wax or other plastic material adhering attached to a documents as a evidence of authenticity or attestation; ...

と説明がなされ，次いで

(B) A token or symbol of a covenant; ...

が説明され，順位としても封印としての seal が優先されている。

また私自身が英語を母語とする英米人（複数人）に対して行なった質問の回答でも 全ての人が Seal には「封印」の意を強く感ずるとのことであった。

(5) L. Legrain, Ur Excavations, vol. X. 1951 ではタイトルに Seal Cylinder な る語が用いられているが,こ扎はまさしく印章」の意である。また同書 Introductory 
Note の文中では flat stamp seal といら語が「(押捺用の) 印章」の意で用いられ ている。いずれにせよ『seal という単語は「印章」であって「封印」ではない』とい らのは堀氏の思いこみ以外の何ものでもない。

(6) L. Legran, Ur Excavation, vol. X 1951 の Descriptive Catalogue の中で impression on Clay sealing といら熟語として用いられている。な秥ここで重ねて言 らが堀氏は impressionを「封泥」と考光て执られるが impression は押捺印によっ て印された「文様，図柄」のことであり Clay sealing こそ「封泥」なのである。 seal の動詞としての用法には「印を押す」「〜飞調印する」といら用法があり，

また Seal up「封をする」といら例も存在する。堀氏は sealing を単独に用い て「封印・封泥」として扔られるが Kenkyusha 1960，Oxford 1968 いずれの辞 典でも sealing 単独の意味としては「オットセイ(あるいはアザラシ) 猟」の意し か認められないのである。

(7) L. Legrain, Ur Excavation, vol. III 1936 では Seal-Impressions のタイトル で「印面・図柄」の集成を行なっている。重ねて記すが impression には堀氏の言う 「封印」の意味は全く認めることが出来ないのである。

（8）堀氏の引用した原典をチェックすることが出来なかったので私の挿図に引用し得 なかった。オリエント誌35-2（1992）の堀氏の書評論文挿図 3-d (p. 151) 学参照さ れたい。

\section{搟図キャプション}

出土地/資料出典

Fig. 1, 円筒印章印影 Ur, Pit W. U. 18413/L. L. Legrain, Ur Excavations, vol. III; Archaic Seal-Impressions 1936 (以下 Ur Excavations 1936), PL. $11-215$

Fig. 2, 円筒印章印影 Ur, Pit W. U. 14769/Ur Excavations 1936, PL. 11-217

Fig. 3, 円筒印章印影 Ur, Pit W. U. 18143/Ur Excavations 1936, PL. 10-214

Fig. 4, 円筒印章印影 Ur, 出土地点不明 U. 14789/Ur Excavations 1936, PL. 14274

Fig. 5, 円筒印章印影 Ur, Pit D U. 14599/Ur Excavations 1963, PL. 16-302

Fig. 6, 円筒印章印影 Uruk=Warka Eanna $\mathrm{N}$ a or b/今井綾子 原歴史時代と初 期王朝時代の印章様式の発展——最近の印章研究の諸問題——古代オリエン 卜博物館紀要 X 1988-89, Fig. 3 P-112

Fig. 7, 円筒印章印影 Ur, 出土地点不明 U. 14662/Ur Excavations 1936, PL. 17330

Fig. 8, 円筒印章印影, Ur. 出土地点不明 U. 14559/Ur Excavations 1936, PL. 18348

Fig. 9， ワシと旗章浮彫, Hatra, イラク博物館蔵/R. Girshman, Iran, Parthian and 
Sassanian, London, 1962 Fig. 2

Fig.10, ワシ小像 (青銅製), Dura-Europos, 左. h. $5.7 \mathrm{~cm}$ ダマスクス博物館蔵, 右, h $4.8 \mathrm{~cm}$ イエール大学蔵/M. I. Rostovtzeff et al (Ed.), The Excavations at Dura-Europos conducted by Yale University and the French Academy of Inscriptions and Letters, Prelminary Report of the Ninth Season of Work 1935-1936, Part III The Palace of the Dux Ripae and the Dolicheneum, Yale Univ. Press 1952 (以下 Dura Europos) PL. XXIII-1

Fig.11，ワシと旗章浮彫, Hatra，イラク博物館蔵 IM 48151/Malcolm A. R. Colledge, Parthian Art, London, 1977 Fig. 34

Fig.12，建築装飾ワシ浮彫， Palmyra， h. 85 cm，パルミラ博物館蔵 1906/6550 / K. Tanabe (Ed.), Sculptures of Palmyra I; Memoirs of the Ancient Orient Museum, vol. I, Tokyo 1986 (以下 Orient Museum 1986) PL. 84

Fig.13, 建築装飾ワシ浮彫, Palmyra, h. $24 \mathrm{~cm}$, パルミラ博物館蔵/Orient Museum 1986, PL. 86

Fig. 14, 建築装飾ワシ浮彫，Palmyra， h. $89 \mathrm{~cm}$ ，ダマスクス博物館 No. 16441／ Orient Museum 1986, PL. 123

Fig.15，アッシュールニベル神像に附されたワシ浮彫, Hatra, h, $2.0 \mathrm{~m}$ (神像高), イ ラク博物館蔵／深井晋司 世界彫刻美術全集 2 オリエント，小学館 1976, PL. 125

Fig.16, 封印印影人物像, Dura Europos, イエール大学蔵/Dura-Europos, Preliminary Report of the Third Season of Work Nov. 1929-March, 1930, PL XIII-2

Fig.17，線画人物像 (陶片), Assur / R. Ghirshman, Iran, Parthian and Sassanian, 1962, Fig. 60

Fig.18, 封印印影ワシ, Tell Kashkashok/T. Matsutani (Ed.), Tell Kashkashok, The Excavations at Tell No. II, Tokyo 1991 (以下 Kashkashok 1991) PL. 52-1-b

Fig.20. 封印印影 Tell Kashkashok/Kashkashok 1991 PL. 52-1-C 

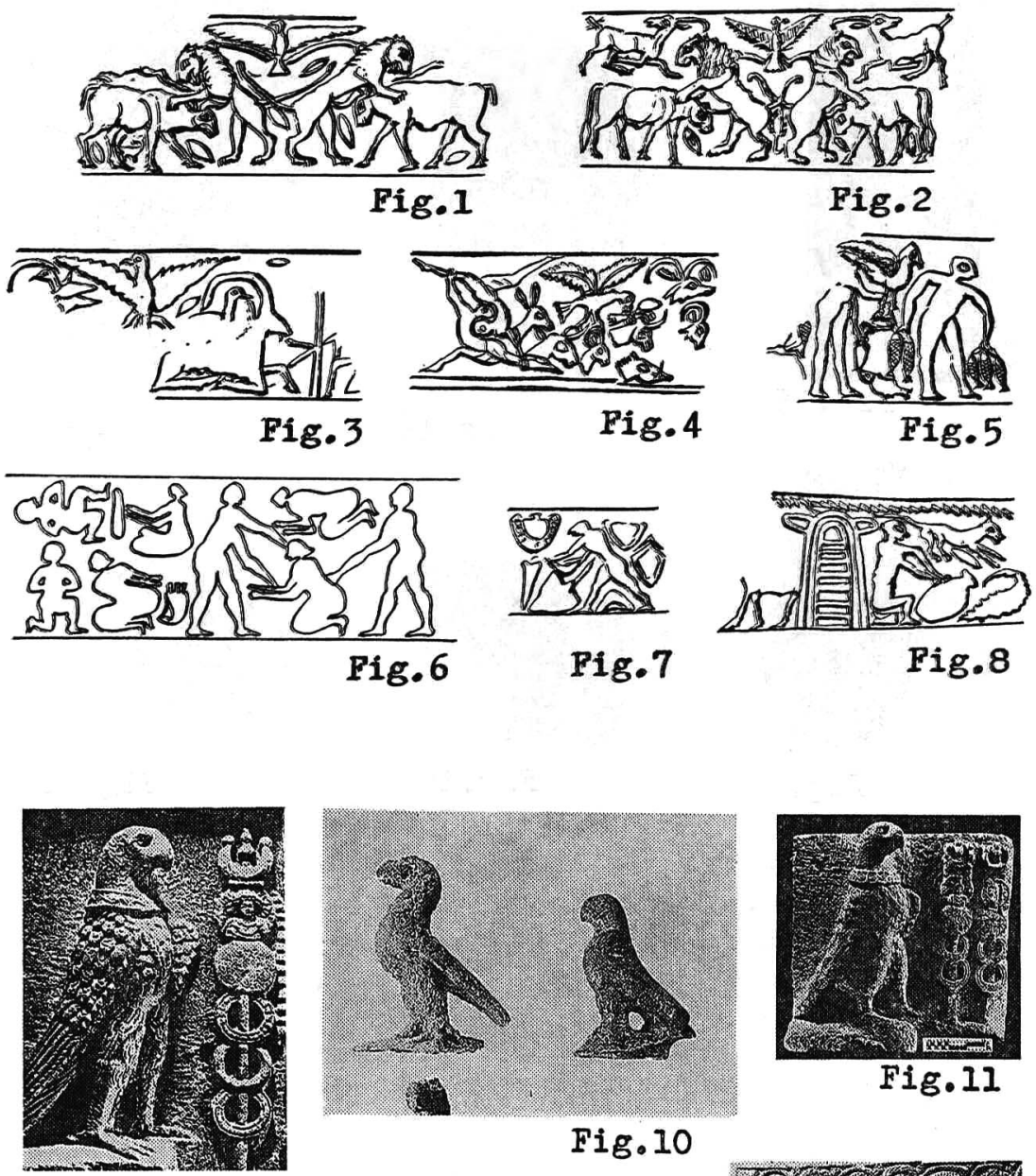

\section{Fig.10}

Fig.9

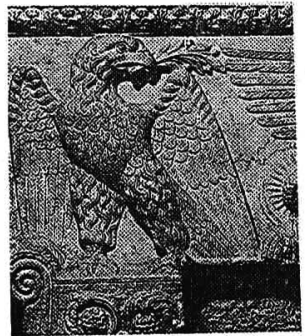

Fig.12

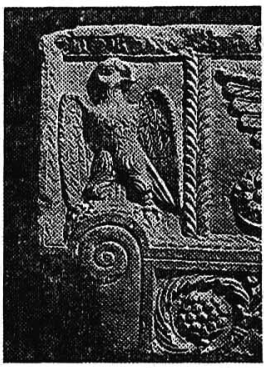

Fig.13

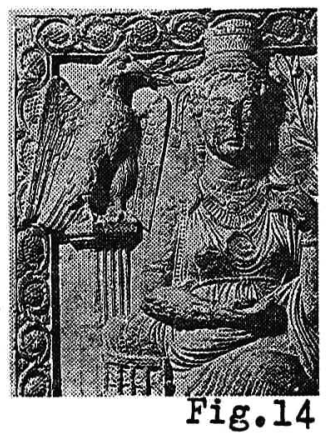



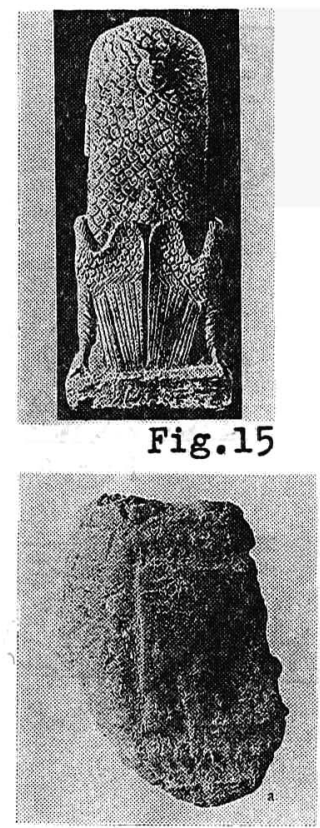

Fig.18
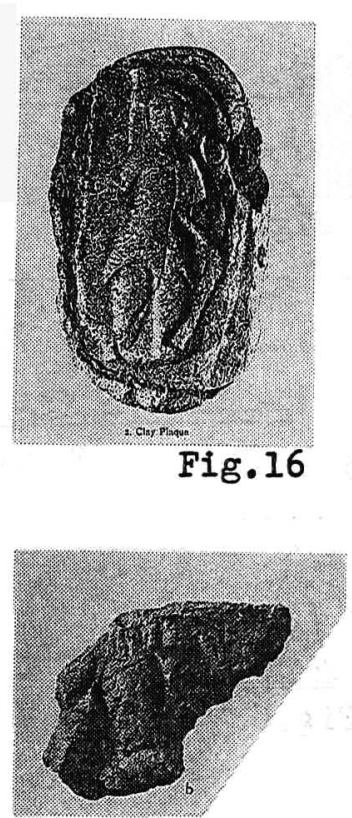

Fig.19

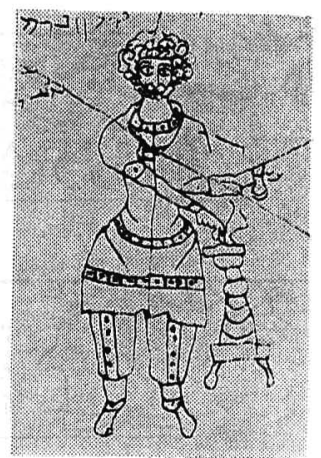

Fig. 17

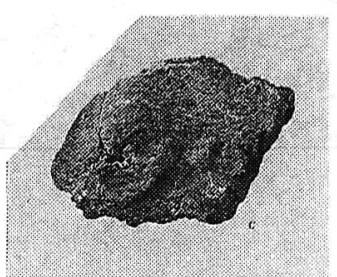

Fig. 20 


\title{
テル・カシュカショク第 2 層の真相
}

——書評』に応えて——

\section{The Truth and Re-examination of Layer 2}

\author{
小泉 龍 人 $^{*}$ \\ KoIZUMI Tatsundo
}

\section{はじめに}

『オリエント』第35巻一2号（1993）に，堀晄氏（以下評者とする）が「テル・カシ ユカショク発掘報告書をめぐって」といら題目で書評を投稿された（以下書評とする）。 評者は，冒頭で次のように述べられている：「テル・カシュカショク発掘報告書の（途 中省略）内容に関して批判，疑問点を提出し，報告者からの反論を受けたいと考えたの である」。批判や疑問点を提示するのは良いことだが，果たしてこの書評は一体どのよ らな論理的手順に導かれているのか?正直な読後感はこのよらなるのであった。

本稿では, テル・カシュカショク遗跡を発掘調查した東洋文化研究所のチームの一員 として，また，微力ながらる西アジアに和ける先史文化の解明に日々悪戦苦闘している 学徒の一人として，書評汶する反論を試みて見ようと思う。実際には，「反論」とい らよりる「真実の解明」といった方がより正確であるら。つまり，書評には明らかに事 実誤認と断定できる箇所が多数見られ，間違った認識に基づく論の展開が䂏觉るのであ る。筆者は, この「勘違い」あるいは「誤認」を懇切丁寧に訂正しながら，自身の見解 と評者のそれとの相違をはっきりさせていこうと思う。手順としては，まず最初に事実 誤認をただし，次に評者と筆者との間にある見解の相違について触れながら，筆者自身 の解釈・見通しを紹介してみたい。あくまでも筆者は，何か勘違いで，何が真の問題点 なのかをきちんと整理すべく筆を執ったのである。

\section{1. 第 2 層の概説}

テル・カシュカショク遺跡第 II 号丘に捺第 2 層の簡単な紹介をして見よう。北シ リアのハブール川流域に立地するテル・カシュカショク遺跡は, 1987年と1988年の 2 シ ーズンに渡って東京大学東洋文化研究所の調查隊によって発掘された。このII 号丘は, 主に西側斜面を中心にトレンチ発掘が行われ, 調查終了時までには, 過去の生活復元が十 二分に推測しらる程に発掘面積が広げられて行った。なかでも第 2 層と命名された堆積

* 早稲田大学文学部助手

Research Associate, Department of Archaeology, Waseda University 
層に帰属する墓壙群が発掘区画一面に広がって拉り, その副葬品から推定してウバイド・ 「ウルク」期(注) に該当するものであることが予想された。発掘の際に100以上の墓が発 見されたが，このうち副葬品があるか，もしくは構造が明膫に認識できる63基が登録さ れた (Koizumia 1991：59/以下ページ，図版等の番号を記載)。墓の構造は特異な形 態を示して括り，まず垂直方向に堅穴（シャフト）が掘られてある程度の深さにまで達 すると，今度はシャフト底面から水平方向に堀り進められて墓室が形成される。この墓 は，ちょうど断面で観察すると地下式横穴とでも言うべきプランを呈している。埋葬後， 墓室入口（羡門）に，日干しレンガが数段積まれて閉塞されたと想像される（㷒 1 ）。 この墓壙形成に就ける独特な方法は，これまで他遺跡ではあまり正確に確認されていな いものであり, 北メソポタミアのなかでハブール流域に位置している諸遺跡の拡がり

（流域圈ないしは地域圈）を検討する上で有効な指標になると考兄られる (pp. 62-64)。 ほとんぞすべての墓は，プランに拈いてある一定のパターンを有している。つまり， 必ずと言ってよい程，墓室の北側（東西方向に若干片寄る場合もある）にンンガ列が残 存しているのである。この事実から本報告では, 一貫して観察される構造上の特徴, 埋 葬状況，副葬品の種類や配置などについて具体的な事例を用いながら説明し，規則的な パターンの部分的変異, 著しい例外などもくまなく記載していった。各事例に括ける其 体的なプラン, レンガ列, 袖レンガ, 枕, 頭位, 顔の向き, 副葬品の種類・配置・推定 時期, 切り合い関係は, 表 (Table 9) 飞まとめた。登録された墓に関する情報はほとえ どこの表に包含されて抒り, 実測図および写真による情報と併せてカシュカショクのウ バイド・「ウルク」墓が復元できるよらに意図されている。

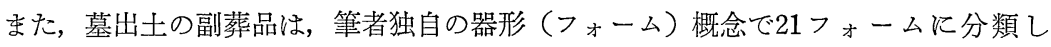
た。ここでは, 容器端部に和ける立ち上がりの指向性と胴部断面の形状といら 2 つ変 数から構成されるフォームを主に設定し, 各フォームの形態的特徴や文様表現について の情報を列挙して行った（pp. 67-76）。各サンプルに括ける胎土，表面調整，焼成など の観察記録は，巻頭のリストに一覽してみた (List of Plates)。各フォームにおいて比 較資料となるような他遺跡に打ける類例を適宜引用した。筆者は, 土器編年に関して慎 重な姿勢で臨み, 後日編年構築する際の便宜を考慮しながら事実記載に徹底した。編年 については別稿で詳細に論じているので (Koizumi in press), 本稿では適宜その一部を 紹介するに留める。

\section{2. 事実の誤認}

では早速, 書評で取り上げられている事実関係の真偽について順を追って詳しく吟味 してみよう。ここでは書評中の文章を引用し, 該当部分に和ける事実関係を究明して行 

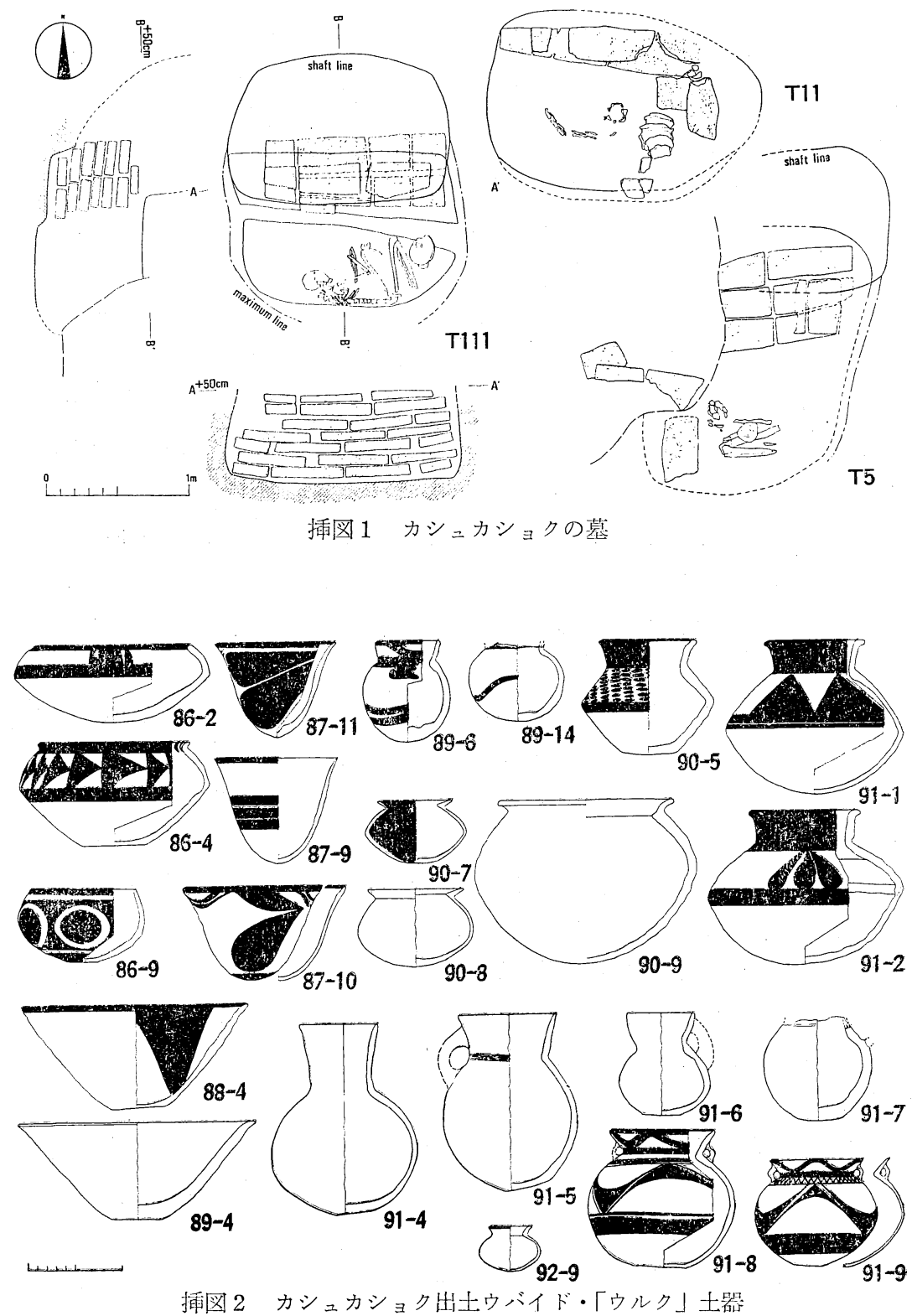
<(挿図 1,2 参照)。

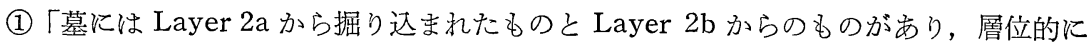
区別される (p. 59)。しかし，参照するようにと指示された P1. 56 から読み取れるのは ……」（書評 : 148)。

PLs. 56, 82-2 ; Table 9 の3つを参照するようにと指示したのに，なぜか，PL. 56 だ けが引用され， T $110 \cdot 112 \cdot 116 \cdot$ Tomb just north of T 110 (2a or $2 \mathrm{a} ?$ ?)やT 125 ・129 (2b?) といった, PL. 82-2 拞よび Table 9 に明記された他の墓壙は無視され ている。同時に, 評者は, $\mathrm{T} 15,111$ といら東西方向のセクション図に載っている墓壙 を，南北方向の同図にある墓壙と同格に並べて論じてしまっている。カシュカショクで 見つかった墓壙は，上述したように，北側にシャフト，南側に墓室といら構造が基本的 に採用されている。つまり，その性格上，南北方向の断面では墓室天井部のレヴェルよ りも高い位置にシャフトの掘り込みが残っているので（地表下に同構造の墓壙を造るこ とを考えれば至極当然であるが)，「墓壙」自体の掘り达み面としてシャフトの掘り込み 面をほぼ正確に捉えることができる。一方，東西方向の断面では，墓室天井部あるいは シャフト側面のライン（シャフト残存部における特定レヴェルでの輪郭）が見学る場合 が多く, 実際のシャフト掘り达み面とは認定し難い。こうした観察結果を踏まえると, 墓の掘り込夕面として使朰る情報は, 南北方向のセレクション図に載っているものに限 定されるわけであり，これは Table 9 にすべて盛り込まれている。したがって, 評者 が墓の特殊な構造を無視し，しかも他の図表に拉ける情報を顧みずに論を進めてしまっ たのは早計であろら。

(2)「T 18 はJ・オーツの言う Terminal Ubaid 期である（p.62）とされ，との根拠と して T 18 に副葬されていた広口の鉢 (P1. 88-4) がガウラ遺跡 XI-A 層 (即ちウルク 前期，ないしウバイドーウルク移行期）のもの (Tobler 1950, P1. CXLI-328) に近いこ と (p. 71), 鉢 (P1. 86-4) が同じガウラXII 層のもの（同上書 Pl. LXXIX-f）に酷似す る（p.65, Note 1) が指摘されている」(書評：148-49)。

PL. 88-4（T 18） は報告書の中では特にそれだけで他遺跡出土の類似品と比較されて いない。筆者が上述のガウラ XI A 層出土品と比較しているのは PL. 89-4 (T 109) の 方である。評者は，T 18 の副葬品の一つとして PL. 88-4 を引用したときに, PL. 89-4 とガウラ出土品の比較の件を勘違いして拾ったようである。この事実呮認に基ついて, T 18 の帰属時期が推測されてしまっている。

(3)「……副葬された土器の一つ (P1. 90-5) をハラフ式土器として認定してしまったた めであろら (Table 9, Notes) が，胎土やスリップ（xxxii の説明に淡緑色とある）， 顔料，焼成などは他の土器と変わらず，ハラフ土器と認定する必然性は極めて薄い」 
(書評 : 149)。

評者は, PL. 90-5 の「胎土」が他の土器と変わらないと指摘しているが, 報告書の観 察覽 (xxxii) では「灰色胎土“Gray paste”」と記述されている。副葬品として出土し た他の土器は，「赤褐色 “Redish brown paste”」「赤色 “Red paste”」「茶色 “Brown paste”」といった色調の胎土を有するものが主流であり，明らかに「灰色」の胎土とは 異なっている。しかも，この特異な色調の胎土をるつ土器は PL. 90-5一点のみであ る。これは, 他のウバイド・「ウルク」土器と明膫に区別される。器形・文様の点でも この土器がハラフ期めるいはウバイドのかなり古い時期に帰属することが言える。アル パチヤのハラフ期“TT 7 or earlier”から, 胴部に緩い稜を持ち, 頸部から口縁部にか 㐌てやや外反しながら立ち上ぶっていく平底の壷が見つかっており（Mallowan and Rose 1935: Fig. 64-3，9), 独特の「卵形（棈円形）斑点文 “egg or oval stippling”」 が目立って採用されている（Mallowan and Rose 1935：Fig. 64-6，7，9，10)。またり ンゴルAのウバイド墓からは, 胴部に稜を有し, 頸部から口縁部にかけて外反している 壶が出土して和り，不規則な大きさの「斑点文」が上胴部に施されている（Kamada and Ohtsu 1991: Fig. 4-P. 5)。したがって, カシュカショク T 3 出土の PL. 90-5 は, 北方ウバイド後期よりも同前期初頭あるいはハラフ期終末に比較相当すると考えら れよう。

(4)「また，テル・ブラックの例 (Oates 1987a, Fig. 3-10) は大型の赤色磨研土器で全 く範疇の異なるもので，比較すること自体が変である」（書評：150）。

筆者は報告書の記述の際に“red burnished ware”と明言しなかったが，PL，90-8， 9 はまさしくこのブラク (Early Uruk stuctures) 出土の「赤色磨研土器」と同一グル ープに帰属すると考えられる。その根拠としては, 表面の丁寧な磨研調整（fine burnished surface; highly burnished), 植物質の混和材を含さ胎土 (straw temper; chaff-faced), 褐色あるいは暗茶色から橙色にかけての色調 (red or reddish brown paste(slip); pale brown to orange surface), といった点が挙げられよう（p. xxxii； Oates 1987a：197)。書評では, PL. 90-8, 9 の表面調整や色調に関する記載項目が見落 されてしまっているよらだ。また，ハマームV V からも “orange or red-slipped burnished pottery”が確認されて和り (Akkermans 1988b：312-13), 該当土器が「ウ ルク」前期に比定されるのはまず間違いなからら。

(5)「筆者にもこの土器の類似例は今のところ指摘できないが, 土器の製法や胎土, 表面 処理が他と異ならず，しかも同じ墓地の同じ様式の墓から出土しているのだから，とり あえずウバイド期相当として特くのが当然ではなかららか」（書評：150）。

ここでは，T 4, 5, 11 から出土した “Jars with short everted necks” (PL. 90-7, 
8，9）が問題とされているが，評者が根拠としている項目を吟味して見ると, 報告書に 記載されている内容と全く異なることがわかる。まず，これらの土器の製作法である が，PL. 90-7 (T 5) は, 内面底部に径 $1 \mathrm{~cm}$ 位の指頭圧痕が見られ, そこから上方に 向かって平行に並ぶ細かい線状痕が過状に延びている（p. 77)。この証拠は, 土器製作 の段階で「回転台」あるいは「低速ロクロ」が使用された事実を物語っている。カシュ カショク出土のウバイド土器は，「輪積み」で成型されるのが主流であるが，中には PL. 90-7 のように成型・整形の工程で「回転台」あるいは「低速口ク口」が併用され たと思われる例がいくつか見つかっている：PLs. 86-9 (T 136), 89-6 (T 109), 14 (T 107)。したがって, これらの土器は, 製作技法上他のウバイド土器群と一括されるこ となく区別されるべきである。

次に，表面処理に関して，PL. 90-8, 9 (T 4,11) は外面全体に渡って丁寧な「磨研」 が施されて和り, 明らかに他の土器群と区別され得る (p.xxxii)。カシュカショク出土 品の中で明膫に磨研と認定できる表面調整を持つるのは限られて括り, PLs. 87-12・90 -9 (T 11), 90-8 (T 4), 90-15・91-3 (T 116), 91-8 (T109), 92-9 (T 13) といった 程度である（pp. xxix-xxxiv）。ここで注目すべき点は，同一墓壙内に磨研技法が用い られている土器が共伴しているといらことである（T 11，116)。特定の墓に特異な技法 が集中しているといらことから，これらの墓や技法が他の墓壙群や土器群とは時期的に 区別乙得るといえよう。実際に，磨研技法は他遺跡でも特定の時期に目立った存在とな っている傾向が䂓觉る。アルパチヤのウバイド墓地ではあまり報告例が無いのに対し (Mallowan and Rose 1935: 71-72)，ガウラ XI A, XI, X A や八マーム V B とい った「ウルク」期（ウバイド後続期）になると顕著に観察されている（Tobler 1950 ： 152, 155; Akkermans 1988b : 297)。

さらに，墓の構造について，T 11 では「袖レンガ」“wing bricks”が墓室北側のレン ガ列東端に接して特り（pp. 60，62，PL. 79-4，Table 9)，レンガ列だけが墓室北側に 配置された一般的な形態の墓壙とは明膫に区別される。「袖レンガ」には，墓室内に位 置するものと（T 11, 18, 108, 109, Tomb northern to T 110), シャフト内に位置す るものとがある (T 25, 102，110)。主にとの副葬品から判断して，前者はウバイド終末 期あるいは「ウルク」前期，後者は「ウルク」後期に气れぞれ比定される (p. 62)。T 5 はレンガ列が 3 列となって和り，一列めるいは二列酒置されている通常のパターンと は異なる（p. 60，PL. 79-2, Table 9)。他には，T 23 が墓室北側に三列を有している のが確認されているが, 副葬品が見つかっていないので帰属時期に関しては, はっきり としたことが言光なかった（p. 60, PL. 80-4, Table 9)。T 4 はプランが不明であり，構 造上の比較はできなかった（Table 9)。 
以上，書評で取り上げられている事項の中には，報告書の記載と異なる箇所や，見落 されてしまった部分があり，被評者としてはとても残念であった。

\section{3. 見解の相違}

次に，筆者の見解と評者の見解が異なっている部分について検討して見る。

(1)「カシュカショクでの墓地構造や葬法の解明は，北シリア先史文化研究の基礎となる はずのものである。それにもかかわらず，発掘されたらちのごく少数の墓しか図化され ていないのは納得できない」（書評：148）。

墓璌群のデータは，類似した事例から成り立っており，構造・葬法に永いていくつか のパターンが看取された。そこで，全ての事例を単調に羅列するよりも，観察される上 で必要不可欠な傾向をカヴァーしている複数の事例を図化し，全体のデータは表に屯と めるという手法を報告者は選択している。図示した資料と表中のデータで全体像が十二 分に把握できると信じているし，図化していない資料（ほとんどが類似したデータ）を 引きずり出して墓地構造や葬法の解明にどれだけ新たな貢献ができるか疑問である。た だ，事実はできるだけ全て図化すべきであるという視点から見るならば，例示数が足り なかったように思う。また, 墓壙の時期, 副葬品としての土器群の編年に関しては, 十 分な検討・考察を経た後に, 納得のいく説明が行われなければならない。特に編年構筑 に执いて, 安易かつ慎重さに欠ける比較分析は極力排除しなければならないのは当然で ある。そこで，筆者は，編年「案」を披露してしまらにはまだ早急すぎると考光，極力 個人的見解を避けている。

(2)「しかし，報告者側は充分な情報を持っているはずで，基本的な層位による分類が無 意味だった（その場合は層位認定の誤りの可能性を含む）のかどうかも記述されていな いのは解せない」（書評：148）。

報告書では山らかじめ，残存状況がよくないため，墓がどの層から掘り込まれたのか 決めるのは難しいと断わって和り（p. 59), その撖しい状況下で敢觉て Layer 2a, 2b か ら掘り达まれたものを抽出したのである。そこでは, これらの事実を「層位差」あるい は「時期差」の判断基準として積極的に用いるのではなく，「構造」上掘り达み面から ぞの位の深さを有しているのか，といら情報として用いているのである。したがって， 報告書では，掘り込文に関しては“Structures”の中で报って括り，単独で「層位」あ るいは「編年」といった項目を意図的に設定しなかった。実際に掘り込みがある程度確 認された墓はこれこそ全体のごく一部にしか過ぎず（本稿 2 -1 (1参照)，汇んの一握り の証拠をるってして墓壙群全体の編年を語るのはとても危険である。

(3)「後者 (PL. 86-4) と同形式の土器はハマーム・トルクマンの IV-D 層にも出土して 
おり (Van Loon ed. 1988, Pl. 93-282)，ウバイド後期の範疇外とは言い切れない」（書 評 : 149)。

ハマーム IV D は，ガウラ XII A, XII あるいはレイラーンVI b の後半と時期並行す る(Akkermans 1988:226-27) という相対編年から，筆者は，PL. 86-4をウバイド期の 終末に位置する “Terminal Ubaid”という時期に帰属させたのである。この時期は，明 らかにウバイド後期（ガウラXIII，ハマーム IV C, レイラーンVI b 前半）とは区別す ベきである。しかし，評者の主張は，ガウラXIIに出土している類似品がハマーム IV D にも見つかっているので, PL. 86-4 はウバイド後期に含まれるといら主旨である。この ような推測をするからには, 評者は従来の相対編年（ハマーム IV D とガウラXII が時 期並行）とは異なる時期差を想定しているという印象を受けてしまう（でないとしたら， これも単なる勘違いとなってしまらのだが…..)。せぬてガウラ XII が一体どの時期に 位置するのか一「ウバイド後期」に属するのか, あるいは「ウバイドーウルク移行期」に 属するのか一をはっきりとして和いて欲しかった。繰り返すが，筆者はガウラ XII A, XII を“Terminal Ubaid” に時期相当させる編年案に同調している。

(4)「さらに, 同墓出土の P1. 91-2 の壼に描かれる水滴文がウバイド後期の特色である ことは,エリドゥの発掘結果からも明らかであろら（Safar etc. 1981, Pl. 7)」（書評： 149)。

ここでも，T 18 から出土した副葬品を引用しながら，いかにこの墓がウバイド後期 に帰属するものであるのかが力説されている。しかし，他の副葬品を眺めると， PL. 86 -4 がガウラ XII，ハマーム IV D といった “Terminal Ubaid” 出土の事例と類似して いる。また墓の構造に括いても，北側のレンガ列西端に「袖レンガ」が接して拈り(PL. 80-3), 上述のようにウバイド終末期あるいはそれ以降の時期に比定され得る。したが って，T 18 がウバイド後期に帰属するといら評者の推定根拠としては，PL． 91-2 の文 様である「水滴文」のみしか残ってこなくなり，T 18 をウバイド後期に帰属させる根 拠としては不十分である。筆者は，特定のモチーフだけで他地域と安直にクロスデーテ ィングさせてしまらことは控えたいので，現状では T 18 をウバイド終末期に比定させ るのが妥当であると考える。

(5)「T 3 etc. は Early Ubaid 期（p. 63）とされるが, “etc.”が一体何を指すのか理解 できない。しかも，T 3 から出土した土器 (PL. 87-10) はエリドゥの Cemetery を特

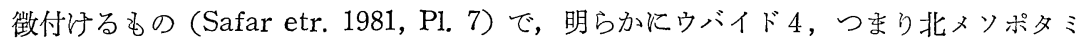
アのウバイド後期に属すると思われる」（書評：149）。

T 3 以外の墓壙からも, 他遺跡のウバイド前期 “Early Ubaid” 層で見つかった土器 と類似している「器形(フォーム)」が比較検討されている。T 24 出土の “Bowl with 
sharply incurved, carinated vessel wall” (PL. 86-2) は, サラサート XIV (Fukai, Horiuchi, and Matsutani 1970: PL. 77-6) やレイラーン VI A (Schwartz 1982: Fig. 52-6）といったウバイド前期の資料と類似している（pp. 67-68）。 また，“Hemispherical bowls” “Globular jars with rounded bases”などのフォームが，他遺跡 のウバイド前期層（ガウラ XVI・XV，サラサートXIV，アルパチャ “deep levels; main graves”) から出土した土器とそれぞれ比較されている (pp. 69，72)。ただ，前者に特 いては他の副葬品（PL. 91-1，4）がウバイド前期に属するかどらかの比較検討が難し く, 後者のフォームでは共伴遺物の比較もさることながら, 該当フォーム自体の比定時 期に幅があることが予想された（pp. 69，72）。したがって，ウバイド前期に帰属する 墓壙の存在は T3 以外にも予察されたのだけれども，まだ推定できる程に確証が得られ なかった。上記の表現を報告書中に用いた言い訳をすればこうなるが，評者の指摘して いる通り“etc.”といら曖昧な表現は不親切であったと反省している。

また，PL. 87-10の帰属時期についての見解であるが，筆者は“Cup-like vessels”の 位置付けを以下のように考えている。このフォームはいわゆる“Bell-shaped bowls”の 変形あるいは変異と考えられ, 両者の器形上の差異は, 器高が口径の 4 分の 3 (口径の 半分の1.5倍）以上あるものは前者，以下のものは後者としている（p.69）。全体的な 印象としては, 前者が“tall”で，後者が“squat”である。さらに，後者のフォームには 底部直上に水平带状文が彩色されていることがよくある。この “Bell-shaped bowls”と 特定の部位に施される彩文の組み合わせは, アルパチヤ “main graves” (Mallowan and Rose 1935: Fig. 29-1, 2, 4) やガウラ XIX-XVII (Tobler 1950: PLs. CXX-83, 87, CXXI-91) に見られ，北方ウバイド前期の前半（南方ウバイド $3 a$ 期に相当）の指 標として用いられることが多い(Oates 1987b: 482; Porada, Hansen, and Dunham 1992: 90)。他方, “Cup-like vessels” は, ウバイド前期後半（ウバイド 3b）からウバ イド後期に集中している（Oates 1987b：482；Akkermans 1988a：223)。以上の事実 関係より, カシュカショク出土品の推定時期は北方ウバイド前期の後半以降に落ち着く ことになる。そして PL. 87-10 は，同一フォームである PL. 87-9，11 に比べるとや や低めの器高と底部に見られる彩文が上述の「組み合わせ」を想起させ，ウバイド前期 後半に帰属する可能性が強くなる。この推測は, T3 出土の他の副葬品である PL. 905 の比較分析からも十分に補強され得る。

加光て, PL. 87-10 の「水滴文」はエリドゥに括いて VIII・X 層 (Safar, Mustafa, and Lloyd 1981: Figs. 82-17, 86-17) といった南方ウバイド3期（北方ウバイド前期 相当）層からも出土して括り，必ずしもウバイド 4 期（北方ウバイド後期）に限定され

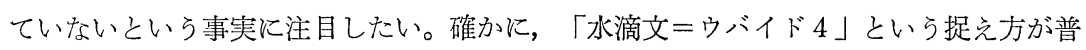


及しているものの, 新しい情報を既成の節にかけるだけで終わらせずに, 別の角度から 見直す作業にも何らかの価值を見い出せるはずだ。この「器形」あるいは「文様」とい ら視点の相違による解釈のずれは今後慎重に扱らべき問題点であろう。

(6)「T 13 とT 109 から出土した両把手付の土器 (Pl. 91-8，9, 挿図2-14) は形態, 文 様とも酷似していると述べる (p. 75) 一方で, Table 9 では前者をウバイド/ウルク期 に, 後者をウルク期に位置付けており, 読者は混乱してしまう。…この形態の土器は ハマーム・トルクメンでは IV-A, B 期 (Pls. 74, 79), つまりレイラーン VI a 並行期 に限定されているのである。」（書評：149）。

PL. 91-8, 9 と類似した器形は, 確かにハマーム IV A ・ V B (Akkermans 1988a： Figs. 74-95, 79-156), サラサート XIV (Fukai, Horiuchi, and Matsutani 1970: PL. 78-1,2,3)，ガウラ XVI・XIII (Tobler 1950 : PLs. CXXVI-153, CXXX-213) という ウバイド前期あるいはウバイド後期から見つかっている。しかし，これらの類似品とカ シュカショク出土品の間灿大さな差異が観察される。まず，その頸部に付けられたル ープ状の把手が極めて小さいのが大きな特徴である。他の把手付壼 “Jars with single loop handles” (PL.91-5, 6, 7) の把手に比べても, その差は歷然としている。しかも, 前者は残存状況が良好でかつ使用痕が残っでららず（p. 75）, 後者は残存状況が悪く明 らかに使用されたと思われる。よって，PL．91-8，9 の把手は実用性といら機能が薄れ て行った一種の「退化器官」として捉光られ, 他の類似品より遅れた時期に位置付けら れるのではなかららか。次に，頸部が鋭く折り返され気味になっているのも目立つ。他 遺跡出土の把手付壼は, これほど角度をつけて折り返されてはいない。このフォーム以 外の土器 (Jars with short everted necks) においても, 頸部が鋭く折り返される傾 向がウバイド前期よりも以降の時期に色濃く現われている（p. 73）。

さらに，類似器形の胎土を調べて見ると，ハマーム IV A, B 出土品は植物繊維 “plant temper”を含まず，代りに石灰質の混和材 “lime temper”を多く含んでいる (Akkermans 1988a：240，250)。この特徵は，ハマーム遺跡における混和材の時期的 変遷からも裏付けられていることであるが (Akkermans 1988a：188-89), カシュカシ

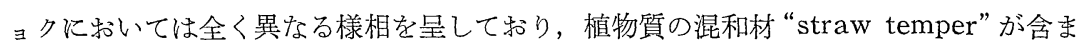
れている。文様について比較して見ても，PL．91-8，9 亿彩色されている独特なデザイ ン（三角形の底辺が鋭く内彎して弧を描いている）は，確かにレイラーン IV a 出土品 (Schwartz 1988：Fig. 68-13）とは類似している。しかし，前者は後者に比べての文椂 の単位が大きく, 両端部がかなり細長く伸びている。この文様配置はむしろサラサート X (Egami 1958: Fig. 55-4) で見つかっているような単位の大きいものとの類推が可能 で，ウバイド前期に限定されることはないと思われる。 
続けて, “Jars with two loop handlts”を有する墓壙の帰属時期について検討して見 る。PL. 91-8 が副葬された T 109 からは “Deep plate” (PL. 89-4) と “Globular jar with rounded base” (PL. 89-6) が共伴出土している。前者は，同一フォームに 属する他の土器と比べてかなり底部が厚い（体部より底部のほうが厚くなっている）と いう点で, ガウラ XI A 出土の類似品 (Tobler 1950：PL. CXLI-328) と比較されてい る（p. 71）。また，後者は製作技法上単なる「輸積み」成型ではなく，「回転台」ある いは「低速ロクロ」を併用した成型であることが観察されている (p. 77)。さらに，墓 の構造自体に执いて，「袖レンガ」を墓室内に持つといら特異な形態を示している。し たがって，T 109 は「ウルク」前期に比定されよう。

他方，PL．91-9 が見つかっている T 13 からは，磨研が施された小型土器 “Small pottery" (PL. 92-9) が共伴出土している。この土器は, 特に他遺跡出土のものと比較 されず，帰属時期を特定するのは難しかった。つまり，T 109 にはウルク」前期に相 当すると思われる土器が副葬されており，他方 T 13 には時期決定 (「ウルク」前期）に 有力な資料がなかった。このことより，T 13 の帰属時期は T 109 に比べてやや古い段 階に落ち着けた方が無難であると考光，それぞれ“Ubaid/Uruk”と“Uruk”といら表 現をした訳である。しかし，本来の器形が “Jars with overhanging rims”之認定され るこの小型土器は，その張出しの弱い鋀状口縁部と稜を持たない球状胴部を考虑して，

「ウルク」期に比定される可能性も捨て切れない。といらのも，この器形の同一变異を 形成している PL. 90-12，13，15 が，その表面に磨研めるいは皇れに近い調整を受けて 光沢を有していることから，「ウルク」期に帰属するかもしれないためである。

(7)「しかし比較された資料のらち，ガウラの土器 (Tobler 1950, P1. CXLVI-409) は高 台を持ち様式が異なる」（書評：149）。

ここでは，「高台」を器形分類に和ける尺度の一つとして捉えるのか，あるいは，底 部形態の一変異と解釈するのかで意見の別れるところである。筆者としては，容器の器 形を「端部の立ち上がり」と「胴部の形態」という2 つの変数を基準にして分類してい るので，高台は「底部」のヴァリエーションとして捉えている。したがって，問題とな っている “Jars with short everted necks”の分類設定において高台の有無は関係な く，むしろ別の視点（地域圈あるいは流域圏）に和いて解釈している。この「高台」の 存在は，カシュカショクの墓壙副葬品あるいはそれに準ずるグループの中には全く見ら れなかった。ガウラではXIII 層で初現し，XII 層で普及してくる（Tobler 1950: 140, 146)。ところが，ブラクではウバイド期から後続期にかけての類例が報告されず，初期 王朝期の後半になってからようやく高台が目立ってくる（Oates 1986: 260, Fig. 4)。 レイラーンに执いてもウバイド期から後続期にかけては高台が僅かに出土しているに過 
ぎず（Schwartz 1988: 51，55，75)，この状沉はハマームでも同様である（Akkermans 1988a : 226；1988b: 310)。チグリス河流域のガウラでは, ウバイド後期からすでに高 台が現われたのに対し，他方ハブール川流域のブラク，レイラーン，カシュカショク， およびバリーフ川流域のハマームではウバイド・「ウルク」期には高台があまり姿を見 せない。つまり，地域圈あるいは流域圈の相違によって，「高台」の出現が頻繁なところ と僅少なところに別れるのである。この現象をいかに解釈するかは今後の課題である。

\section{おわりに}

以上，『書評』に見られる事笑䛊認を修正し，見解の相違を指摘しながら筆者自身の 見通しを紹介してきた。全体を見渡して見ると，明白な事実䛊認に基ついた推測や，思 い入れが強く先走った論理展開が散見された。「論理性」とか「客観性」を力説されて いる評者が，有らぬ「事実関係」の集積から私論を展開されているのは頂けない。特に， 「カシュカショク出土ウバイド土器の編年試案（書評：挿図 2)」なるものを大胆にも 提示されているが，よく見ると同一墓壙に含まれる副葬品が評者のいら「ウバイド前 期」そ「ウバイド後期」にそれぞれ㷌属させられている（同插図2-9：PL. 91-4；2-13， 15 : PLs. 86-2, 91-1)。同一墓壙内に異なる時期の土器が共伴している事象に対する説 明が見当たらず，最後まで評者の意図はわからなかった。書評における編年案は，こう した意味不明の組列や数々の事実誤認から成り立っているため, その有効性を見い出し 難かった。

カシュカショクに和けるウバイド（「ウルク」）土器編年の構築作業で留意しなければ ならないのは, 資料が副葬品として墓壙から出土しているという状況である。副葬品が 故に原位置を保ち, 出土量が少なくても十二分に全体像の復元が可能である。この特異 な出土環境を考慮に入れて，筆者は独自の分類・分析に基ついた土器編年を案出した (Koizumi in press)。ここに大まかな概略を簡潔に紹介して見たい。まず，他遺跡の 同様なコンテキストのもとで出土した土器をカシュカショクと同様に器形分類し, 措定 された各フォーム内での細かい属性変化を層順（他遺跡）に従って組列させる必要があ る。この際, 異なるコンテキストで出土した資料も併せて分析する。次に, 詳細な観察

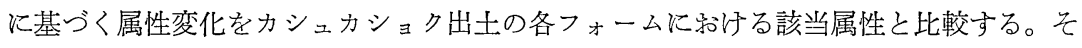
して, 前者に同調させて後者の属性組列を設定し, 属性の集合体としてのフォームの時 間的排列を推定するのである。最後に, 墓における共伴関係と切り合い関係ふら，属性 組列に依拠した編年操作の有効性を検証する。筆者のこらいった分析手法は，ウバイド 編年研究に拈ける諸問題点（Oates 1987b）意識したものであり，ある程度有效な手 法であると考竞ている。 
最後に, 本稿で浮上してきた土器分析に関する課題（上述の問題点も含めて）を以下 に整理して見る。(1)時期推定の際「器形」と「文樣」のぞちらを優先させるかとより設 定時期に若干のず齐が生じてくる，(2)特定の器形あるいは文様は短期間に集中するだけ ではなく長期間に渡って出現することもある, (3)「彩文」や「高台」などの形態属性は 編年だけでなく「流域圈」あるいは「地域圈」を捉光るのにも有効である，といった点 である。唯単に「土器」を比較分析するのではなく，一体何の指標として用いるのか 一一相対編年に括ける「時期」, 分布領域としての「地域圈」あるいは「流域圈」, 出土 環境 (遗構) の性格からみた「機能」一一を峻別し, これらの尺度に基ついて「器形」,

「文様」「製作技法」などの属性分析を詳細に進めて行くべきであるら。

注

報告書では, “Ubaid” の後続期として“Uruk”という用語を使った。この意味すると ころは, “Northern Ubaid Period”（北方ウバイド期）の直後に, 南メソポタミアに拉 けるいわゆるウルク期と時期並行する “post-Ubaid Period”として “Uruk”が位置し ているということである。したがって，北メソポタミアの「ウルク」（本稿ではこの表 記を採用している）と南メソポタミアのウルクとは内容が必ずしも一致しない。

引用文献

Akkermans, P. M. M. G.(1988a) "The Period IV Pottery." In van Loon ed. $1988: 181-286$.

(1988b) “The Period V Pottery." In van Loon ed. 1988 : 287-349.

Egami, N. (1958) Telul eth-Thalathat:The Excavation of Tell II, 1956-57, Vol.

I., The Tokyo University Iraq-Iran Archaeological Expedition, Report 1. University of Tokyo.

Fukai, S., K. Horiuchi, and T. Matsutani (1970) Telul eth-Thalathat: The

Excavation of Tell II, The Third Season, Vol. II, The Tokyo University IraqIran Archaeological Expedition, Report 11. The Institute of Oriental Culture, The University of Tokyo.

Kamada, H. and T. Ohtsu (1991) "Second Report on the Excavations at Songor A : Ubaid Graves." Al-Rāfidān 12 :221-48.

Koizumi, T. (1991a) "Construction of Layer 2." In Matsutani ed. $1991: 59-65$. (1991b) “Artifacts from Layer 2" In Matsutani ed. 1991 : 67-79.

(in press) "Ubaid Pottery from Kashkashok II: Typology and Chronology." Al-Rāfidān 14.

Loon, M. van ed. (1988) Hammam et-Turkman I. Nederlands HistorischArcheologisch Institut te Istanbul, Istanbul.

Mallowan, M. E. L. and J. C. Rose (1935) “Excavations at Tall Arpachiyah, 
1933. "Iraq 2: i-xv, 1-178.

Matsutani, T. ed. (1991) Tell Kashkashok: the Excavations at Tell No. II., The Institute of Oriental Culture, The University of Tokyo.

Oates, J. (1986) “Tell Brak: The Uruk/Early Dynastic Sequence." In Ğamdat Nasr: Period or Regional Style?, edited by U. Finkbeiner and W. Röllig, : 245-73. Papers given at a Symposium held in Tübingen, November 1983. Dr. Ludwig Reichert Verlag, Wiesbaden.

(1987a) “A Note on 'Ubaid and Mitanni Pottery from Tell Brak." Iraq 49 : 193-98.

(1987b) “'Ubaid Chronology." In Chronologies in the Near East, edited by O. Aurenche, J. Evin, and F. Hours, : 473-82. BAR International Series 379 (ii). BAR, Oxford.

Porada, E., D. Hansen, and S. Dunham (1992) “The Chronology of Mesopotamia, ca. 7000-1600 B. C." In Chronologies in Old World Archaeology, Third Edition, edited by R. W. Ehrich, : 77-121. University of Chicago Press.

Safar, F., M. A. Mustafa, and S. Lloyd (1981) Eridu. State Organization of Anitiquities and Heritage, Baghdad.

Schwartz, G. M. (1982) From Prehistory to History on the Habur Plains: The Operation 1 Ceramic Periodization from Tell Leilan. Ph. D. dissertation, Yale University.

Idem (1988) A Ceramic Chronology from Tell Leilan: Operation 1. Yale Tell Leilan Research I, edited by H. Weiss. Yale University Press, New Haven. Tobler, A. J. (1950) Excavations at Tepe Gawra, Level IX-XX. Vol. II, University of Pennsylvania Press, Philadelphia. 